\title{
Показники стану здоров'я сучасних підлітків, як одна із складових здоров'я населення держави
}

\author{
Т.Г. Карпінська', Т.В. Грабовська', С.В. Середа'르, В.В. Короткий' \\ 'Львівська медична академія імені Андрія Крупинського, Львів, Україна \\ ²Комунальне некомерційне підприємство Львівської обласної ради «Центр спортивної медицини і реабілітації», Львів, Україна
}

Анотація. Мета дослідження: визначення та оцінка рівня здоров'я підлітків в Україні. Об'єкт дослідження. Проведено обстеження стану здоров'я 37 підлітків віком 11-14 років за методом експрес-оцінки та визначення індексу форми тіла (A Body Shape Index ABSI). Здійснено аналіз літературних джерел, в яких досліджували та висвітлювали проблеми стану здоров'я молоді. Результати. Виявлено, що 52\% дітей мають середній рівень здоров'я, 16\% - вище середнього, 24\% - нижче середнього, 8\% - низький. Встановлено, що у 62,5\% підлітків рівень спрогнозованої небезпеки смертності дуже низький, у 12,5\% — низький, у 12,5\% — високий та у 12,5\% - дуже високий. Висновок. Проблема погіршення рівня здоров'я серед населення молодого віку залишається актуальною, що зумовлює необхідність пошуку способів їі вирішення для всього суспільства в цілому і для медицини зокрема, що, в свою чергу, допоможе запобігти зростанню рівня смертності.

Ключові слова: здоров'я підлітків, методика ABSI, індекс форми тіла, еспрес-оцінка за методом Г.Л. Апанасенко.

\section{Вступ}

У статуті Всесвітньої організації охорони здоров'я визначено, що здоров'я - це стан повного фізичного, духовного і соціального благополуччя, а не лише відсутність хвороб або фізичних вад.

Проблема збереження здоров'я людини на сучасному етапі існування людства постає дуже гостро, а особливо це стосується юного покоління. Ще з давнини здоров'я було найбільшою цінністю, основною складовою життя суспільства. Воно має велике значення для повноцінного та гармонійного розвитку людини і відіграє визначальну роль на різних етапах людського життя, особливо в підлітковому та дитячому віці. Тоді формується фізичний та психічний потенціал, закладається фундамент для професійного і творчого зростання, участі в сімейно-побутовій та репродуктивній діяльності. Тому серед найважливіших завдань держави $€$ збереження та зміцнення здоров'я молодого покоління. Конституцією України визначено, що людина, іï життя і здоров'я $\epsilon$ найвищими соціальними цінностями країни. Формування здорового способу життя, виховання здорових, всебічно розвинених молодих громадян має стати державним пріоритетом, який об'єднує народ України $[1,2]$.

Згідно з даними наукових досліджень стан здоров'я людини зумовлений на $10 \%$ рівнем розвитку медицини, на $20 \%$ - соціальними та природними умовами, на 20\% - генетикою та на 50\% - способом життя. За останнє десятиліття простежується негативна динаміка зростання захворюваності молоді за всіма класами хвороб. На 30,9\% підвищилася загальна захворюваність юнацтва [3]. Така ситуація спричинена тим, що вже майже два десятиліття в Україні триває глибока демографічна криза, а демографічні процеси у цілому віддзеркалюють сучасний стан суспільного, популяційного та особистого здоров'я людей.

За статистичними даними, до $80 \%$ дітей мають одне або декілька захворювань, лише 15-20\% народжуються здоровими, кожна 3-тя дитина має функціональні відхилення, а у кожної 5-ї відмічають нервові розлади; смертність удвічі перевищує народжуваність. За даними досліджень, тільки $1,1 \%$ дітей $\epsilon$ практично здоровими, а в середньому на 1 дитину припадає 2,5 захворювання. Поширеність захворювань у підлітків України в період 1999-2004 рр. збільшилася на 10 тис. дітей, а темпи приросту становили 10,4\%. На жаль, за даними Центру медичної статистики Міністерства охорони здоров'я України, серед підлітків шкільного віку дедалі більше зростає поширеність усіх захворювань $[4,5]$.
У структурі захворюваності дітей дошкільного та шкільного віку варто виділити збільшення кількості захворювань дихальної, травної, серцево-судинної систем, опорно-рухового апарату, неврологічних хвороб тощо [6]. Це зумовлено підвищенням інтенсивності впливу на здоров'я дітей і підлітків факторів екологічного та медико-соціального ризику, погіршенням структури харчування, зниженням ефективності проведення традиційних профілактичних заходів, популяризацією вживання алкоголю та тютюнопаління [7]. Виходячи $з$ цих даних, можна з легкістю стверджувати, що на сьогодні здорова дитина стає багатством не лише для батьків, але й для держави.

Особливо тривожним $\epsilon$ низький рівень залучення населення нашої держави до занять фізичною культурою і спортом. Так, лише кожен 5-й школяр та кожен 10-й студент мають достатній рівень рухової активності оздоровчого спрямування, що $\epsilon$ одним із найнижчих показників у Європі. Якщо на початку 1990-х років Україна за показниками здоров'я посідала 40-ве місце у світі, то сьогодні вона змістилася далеко назад і займає позицію у 2-й сотні. Це наслідок багатьох чинників, а в першу чергу ігнорування правил здорового способу життя, від якого на 50\% залежить тривалість життя людини $[2,8]$.

Не меншого значення набуває проблема надмірної (НMT) або недостатньої маси тіла. НМТ та ожиріння можуть пояснюватися малорухливим способом життя, невротизацією та нераціональним харчуванням дитини. Згідно з даними Всесвітньої організації охорони здоров'я поширеність НМТ та ожиріння поступово збільшується й посідає 5-те місце у переліку хвороб, що $€$ причинами смерті. У країнах з високим та середнім рівнем доходу, де поширеність НМТ та ожиріння серед дорослого населення вже перевищує 50\%, вони займають 3-тє місце серед факторів ризику, що спричиняють смерть, поступаючись високому артеріальному тиску і вживанню тютюну. НМТ та ожиріння основний вагомий фактор ризику смерті, щороку в результаті цього помирають 3,4 млн осіб. Ожиріння $\epsilon$ фактором ризику розвитку цукрового діабету, ішемічної хвороби серця, онкологічних захворювань. Анорексія (порушення харчової поведінки, що призводить до патологічного дефіциту маси тіла) набула особливого розповсюдження в останні десятиліття і більш характерна для дівчаток підліткового віку [5, 9].

Усі ці фактори негативно впливають на нормальний розвиток та здоров'я молодого населення України, яке $\epsilon$ фундаментом нашої держави, формує прогресивні зміни та розвиток суспільства. Аналізуючи стрімке погіршення показників здоров'я, дедалі актуальнішими стають питання визначення теперішнього 
стану здоров'я сучасної молоді, а також пошук шляхів для його збереження, відновлення та зміцнення.

На особливу увагу заслуговують дослідження з розробки фундаментальних основ індивідуального здоров'я, а саме: міждисциплінарні дослідження механізмів здоров'я та факторів, що на нього впливають, створення баз валеологічної інформації, математичних моделей, експертних систем оцінювання показників здоров'я, інтелектуального забезпечення збереження здоров'я.

Мета: визначення й оцінка рівня здоров'я підлітків в Україні.

\section{6"єкт і методи дослідження}

Проведено оцінку рівня соматичного здоров'я 37 підлітків віком 11-14 років за методикою Г.Л. Апанасенко і визначення ризику передчасної смерті за допомогою індексу форми тіла (A Body Shape Index - ABSI).

Експрес-оцінка рівня соматичного здоров'я за методикою Г.Л. Апанасенко базується на оцінці енергопотенціалу організму, який на певному рівні забезпечує захист організму від розвитку захворювань та робить його максимально стійким до дії факторів ризику. Вона $\epsilon$ ефективною для прогнозування ризику розвитку захворювань серцево-судинної системи, цукрового діабету 2-го типу та ін. При застосуванні експрес-оцінки за Г.Л. Апанасенко визначали життєвий індекс, силовий індекс, індекс Робінсона та показник відповідності маси тіла його довжині, які в подальшому переводили в бали. Це дало можливість визначити рівень соматичного здоров'я. Перевага цієї методики полягає в тому, що вона дає можливість комплексно виміряти антропометричні показники, визначити функціональні показники й провести функціональні проби серед досліджуваних. Крім загальної оцінки стану фізичного здоров'я, ця методика допомагає розглянути всі показники індивідуально, а це дає можливість надати індивідуальні рекомендації щодо оздоровчих заходів $[10,11]$.

Методика визначення ABSI запропонована N.Y. Krakauer, J.C. Krakauer у 2012 р. Цей індекс розроблений як кількісне визначення ризику смертності, пов'язаного з ожирінням, на основі аналізу авторами результатів досліджень (анамнез, медичне обстеження та рівень смертності), отриманих в період 19992004 рр. в ході Національного обстеження здоров'я та харчування у США (National Health and Nutrition Examination Survey). ABSI - показник, для визначення якого використовують окружність талії, індекс маси тіла і зріст, і за цими параметрами розраховують ризик передчасної смертності. Однією з переваг цієї методики $\epsilon$ те, що визначення та інтерпретація даних можливі без участі медичного персоналу, адже в інтернет-мережі поширені онлайн-калькулятори, за допомогою яких можна самостійно визначити даний показник $[9,12,13]$.

Також здійснений аналіз літературних джерел, в яких досліджували проблему динаміки стану здоров'я молоді.

\section{Результати та їх обговорення}

Визначено, що до групи дітей із безпечним рівнем здоров'я, куди віднесені діти з показниками високого та вище середнього рівнів фізичного здоров'я, увійшло лише $12 \%$ обстежуваних. Інші $88 \%$, на жаль, знаходилися за межами безпечного рівня здоров'я.

Середній рівень соматичного здоров'я (середній показник балу середнього рівня соматичного здоров'я $8,15 \pm 0,7)$ виявлено у $52 \%$, рівень здоров'я, вищий за середній $(12,7 \pm 0,43),-$ у $16 \%$, нижче за середній $(5,17 \pm 0,56)-$ у $24 \%$, низький $(3,0 \pm 0)-$ у $8 \%$ обстежених підлітків. Це свідчить про тенденцію до погіршення стану здоров'я, адже основна частка дітей знаходиться за межами безпечного рівня здоров'я.

Аналіз отриманих даних показав, що більше половини обстежуваних (62,5\%) мають дуже низький, $12,5 \%$ - низький ризик передчасної смерті. Високий ризик виявлено у $12,5 \%$ осіб, дуже високий - ще у $12,5 \%$. Таким чином, отримані дані свідчать про те, що переважно ризик передчасної смертності серед обстежуваної молоді $\epsilon$ дуже низьким, що $\epsilon$ позитивним результатом, адже в нашій країні дедалі сильніше прогресує демографічна криза.

\section{ВисновКИ}

За результатами дослідження, у більшості підлітків (88\%) стан здоров'я знаходиться за межами безпечного і лише у $12 \%$ цей показник - на безпечному рівні. Оцінка соматичного здоров'я за методом Г.Л. Апанасенко показала, що у $52 \%$ досліджуваних він знаходиться на середньому рівні, але у $32 \%$ підлітків він нижче середнього або низький, що може бути фактором ризику розвитку в них тих чи інших захворювань.

Спрогнозований ризик передчасної смертності у 75\% обстежуваних дуже низький або низький. Проте серед підлітків вже $\epsilon$ певна кількість осіб з високим та дуже високим ризиком передчасної смерті (25\%).

На наш погляд, однією з основних причин погіршення стану здоров'я підлітків $\epsilon$ недостатньо сформована мотивація на здоровий спосіб життя, яка конкурує з негативним впливом новітніх інформаційних технологій. Суспільству необхідно формувати правильне виховання культури молоді по відношенню до власного здоров'я, стійку мотивацію до ведення здорового способу життя, що дасть можливість покращити стан здоров'я населення і продовжити тривалість їхнього життя.

\section{Список використаної літератури/References:}

1. Andriuchenko T., Vakulenko 0., VolkovV. et al. (2019) Formation of a healthy lifestyle of young people. Educational and methodical recommendations, 2nd ed. Blank Press, Kyiv, 120 p. (In Ukr.).

2. Azarenkov V.M., Azarenkov A.V. (2017) The level of health of pupils and students of Sumy region and the problem of its preservation. Actual problems of physical education of different segments of the population, 12-18 p. (In Ukr.).

3. Seleznyova 0.0. (2014) Health of young people and the formation of a healthy lifestyle (https:// www.narodnaosvita.kiev.ua/?page_id=2513) (In Ukr.).

4. Kolesnichenko M. (2012) The essence of health and its role in the formation of the personality of a preschool child (https://ird.npu.edu.ua/files/kolesnichenko.pdf) (In Ukr.).

5. Nyankovsky S.L., Yatsula M.S., Chikailo M.I., Pasechnyuk I.V. (2012) The state of health of schoolchildren in Ukraine. Child health, 5: 40. (In Ukr.).

6. Belenka G.V., Boginich O.L., Mashovets M.A. (2006) Child health — from the family. Kyiv, 220 p. (In Ukr.).

7. Nechitaylo Yu.M., Buryak O.G. (2016) The health of children and adolescents is the foundation of a nation's health (https://www.bsmu.edu.ua/blog/4349-zdorov-ya-ditey-ta-pidlitkivosnova-zdorov-ya-natsii/) (In Ukr.).

8. Yermolova Yu.V. (2011) The health of young people is a threat to the national security of Ukraine (https://www.umj.com.ua/article/17095) (In Ukr.).

9. Krakauer N.Y., Krakauer J.C. (2012) A New Body Shape Index Predicts Mortality Hazard Independently of Body Mass Index (https://journals.plos.org/plosone/article?id=10.1371/ journal.pone.0039504).

10. Maksimova K.V. (2017) Monitoring the state of somatic health of first-year students of higher educational institutions in Kharkiv. Internat. Sci. J. «Interscience», 7(29): 33. (In Ukr.).

11. Pashinsky P.P., Shcherbak I.M. (2010) Determining the level of health of student youth based on rapid assessment of the functional state of the body. Bull. Sci. works of the H.S. Skovoroda Kharkiv National Pedagogical University. (In Ukr.).

12. Krakauer J.C., Krakauer N.Y. (2016) Combining Body Mass and Shape Indices in Clinical Practice (https://www.hindawi.com/journals/crim/2016/1526175/).

13. Rivas A. (2014) Can A Body Shape Index Take The Place Of BMI? ABSI Proves A Better Predictor of Mortality (https://www.medicaldaily.com/can-body-shape-index-take-place-bmiabsi-proves-better-predictor-mortality-270106).

\section{Indicators of the state of health of modern adolescents as one of the components of the health of the population}

\section{T.G. Karpinska', T.V. Grabovska', S.V. Sereda², V.V. Korotky'}

${ }^{1}$ Andrei Krupynskyi Lviv Medical Academy, Lviv, Ukraine

${ }^{2}$ Municipal Non-Commercial Enterprise of the Lviv Regional Council "Center for Sports Medicine and Rehabilitation», Lviv, Ukraine

Abstract. The purpose of the study: to determine and assess the level of health of adolescents in Ukraine. Object of study. A survey of 37 
adolescents aged 11-14 was performed using the A Body Shape Index (ABSI) method. The analysis of literature sources in which the problems of youth health were researched was carried out. Results. It was found that $52 \%$ of children have average health, $16 \%$ - above average, $24 \%$ - below average, $8 \%$ - low. It was found that $62.5 \%$ of adolescents have a very low risk of mortality, $12.5 \%$ - low, $12.5 \%$ — high and

\section{Відомості про авторів:}

Карпінська Тетяна Георгіївна — кандидат медичних наук, доцент кафедри клінічного медсестринства, акушерства та гінекології Львівської медичної академії імені Андрія Крупинського, Львів, Україна.

Грабовська Тетяна Володимирівна — кандидат медичних наук, доцент кафедри клінічного медсестринства, акушерства та гінекології Львівської медичної академії імені Андрія Крупинського, Львів, Україна.

Середа Степан Васильович - директор комунального некомерційного підприємства Львівської обласної ради «Центр спортивної медицини і реабілітації», Львів, Україна.

Короткий Валерій Васильович - кандидат медичних наук, доцент кафедри клінічного медсестринства, акушерства та гінекології Львівської медичної академії імені Андрія Крупинського, Львів, Україна.

\section{Адреса для кореспонденції:}

Гнідишин Христина Михайлівна

79000, Львів, вул. П. Дорошенка, 70

E-mail:7722kristina@gmail.com
$12.5 \%$ - very high. Conclusion. The problem of deteriorating health among the young population remains relevant, which necessitates the need to find ways to solve it for society as a whole and for medicine in particular, which, in turn, will help prevent the rise in mortality.

Key words: adolescent health, ABSI, body shape index, express assessment by the method of G.L. Apanasenko.

\section{Information about the authors:}

Karpinska Tetyana G. - Candidate of Medical Sciences, Associate Professor of the Department of Clinical Nursing, Obstetrics and Gynecology, Andrei Krupynskyi Lviv Medical Academy, Lviv, Ukraine.

Grabovska Tetyana V — Candidate of Medical Sciences, Associate Professor of the Department of Clinical Nursing, Obstetrics and Gynecology, Andrei Krupynskyi Lviv Medical Academy, Lviv, Ukraine.

Sereda Stepan V. - Director of the Municipal Non-Commercial Enterprise of the Lviv Regional Council «Center for Sports Medicine and Rehabilitation», Lviv, Ukraine.

Korotky Valerii V. - Candidate of Medical Sciences, Associate Professor of the Department of Clinical Nursing, Obstetrics and Gynecology, Andrei Krupynskyi Lviv Medical Academy, Lviv, Ukraine.

\section{Address for correspondence:}

Khrystyna Hnidyshyn

79000, Lviv, P. Doroshenko Str., 70

E-mail:7722kristina@gmail.com 